\title{
Menekültként otthon Kanadában: intimitás a digitális rokonságban
}

„Igyekezzél, hogy ideérjél időben, mert hattól Anyám szülinapját ünnepeljük”, sürgetett Jani, mikor felhívtam a torontói reptérröl, hogy megérkeztem, és egy óra múlva náluk leszek. Jani még mindig tudott meglepetéseket okozni nekem, hiába volt ez már a harmadik, néhány hetes terepmunkám Torontóban. Hogyan ünnepelhetik az édesanyja szülinapját, mikor legutóbb még azon siránkozott, hogy a legnagyobb fájdalma a kanadai kivándorlással az, hogy elszakította a két fiát a nagymamájuktól? „Most, hogy hét év és kétszeri fellebbezés után megkaptuk a menekültstátuszt és ezDurst.Judit@tk.huzel a letelepedési engedélyt Kanadában, nehogy azt hidd, hogy pezsgőt bontottunk Marival. Hiába, hogy erről álmodtunk az elmúlt hét évben, hogy itt maradhassunk. Hogy lehetöséget adhassunk a gyerekeinknek arra, hogy jobb életük legyen, mint nekünk volt otthon... Azért jöttünk ki még hét éve, mert elegünk lett abból, hogy cigányok legyünk Magyarországon... De amikor hét év után édesanyám végre meglátogathatott, én akkor döbbentem rá, mit veszítettünk. A gyerekek ebből a nagymamai szeretetből kimaradtak... Vagyis hát nem teljesen, mert mindennap látjuk egymást a meszendzseren. Anyámat is, meg a húgomat is, meg a többi közeli rokont, aki otthon maradt a falunkban... Nem is tudom, mi lenne velünk a fészbuk nélkül. A pénz jó, ha van, de nem boldogít".

Igyekeztem hát a reptérről mielőbb kiérni Janiékhoz, akik Torontó egyik bevándorló negyedében laktak, egy viszonylag olcsó bérlakásban, amit még ki tudtak fizetni Jani alkalmi munkáiból, Mari, a felesége takarítással szerzett bevételéből, meg a vasazásból. Mire becsöngettem, már hallatszott, hogy hangosan megy a tévé, a képernyő túloldalán folyik az ünneplés. Mari sietett ajtót nyitni, és sebtiben odavetette, hogy ,jó már újra látni”, de gyorsan tegyem le a kabátom, és menjek a képernyő elé, mert most a „mi családunk” (Jani, Mari meg a két fiú mellett családi vendégként én is) következik a mama felköszöntésében. Épp idöben érkeztem: a hetvenedik születésnapját ünneplő Joli néni előtt hosszú sorban felsorakozva álltak türelmesen kicsik és nagyok, a kiterjedt rokonság tagjai, hogy családonként a szoba közepén ülő nagymama, nagynéni, keresztanya (kit milyen rokonsági fokozat füzött az ünnepelthez) elé járuljanak, egy csókot nyomva arcára, és virágot vagy egyéb ajándékot téve a lába elé. A mi családunk is elmondta

A szerző antropológus, a Társadalomtudományi Kutatóközpont Kisebbségkutató Intézet munkatársa. E-mail: Durst.Judit@tk.hu 
a köszöntőjét, a képernyőn keresztül, és a mama könnybe lábadt szemmel mondta a kis Lackónak, hogy ,hála Isten, ti is itthon vagytok velünk, gyerekem, nekem ez a legnagyobb ajándék".

Másnap a meszendzseren megtárgyaltuk Joli mamával az ünnep apróbb-cseprőbb részleteit, majd Mari megbeszélte vele, mit föznek aznap, és hogy holnap tud-e vigyázni a mama Lackóra, mert iskolai szünet lesz, de Marinak muszáj menni dolgozni. (Nekem is volt valami elöre lebeszélt interjúm a város másik végében, így Lackó felügylet nélkül maradt volna, ha Joli néni nem szórakoztatja őt a képernyő túloldaláról). Mariéknál a tévé és rajta a fészbuk három hetes terepmunkám ideje alatt egész nap be volt kapcsolva. Hol egyik, hol másik rokon kukkantott így be Mariék kanadai életébe, nap, mint nap, és teremtette meg azt a kulturális intimitást ${ }^{1}$ ami miatt Jani és Mari Kanadában is „valamennyire otthon” érezte magát. Ez a digitális térben megélt rokonság olyannyira fontossá vált Jani családjának életében, hogy egy nap, mikor elromlott a tévé, Mari teljesen meg volt zavarodva, hogy na, most aztán „marad az idegenség”, ráadásul Joli mama is biztos aggódik, mert nem tudja, nincs-e valami baja az unokáinak, nem azért tüntek-e el a virtuális térből.

Az antropológia és a humán földrajz diszciplínájában készült migrációkutatások egyik tanulsága, hogy a diaszpórában élö migránsok vagy menekültek otthonfogalma, otthonról szóló értelmezései különösen jól mutatják e kérdés komplexitását, és a fogalom újragondolására ösztönöznek bennünket. Egy ilyen újraértelmezési folyamat eredményeként hívja fel a figyelmünket Avtar Brak a Diaszpóra térképei c. munkájában ${ }^{2}$ arra, hogy nem az az igazi kérdés, hogy mi az otthon, hanem az, hogy hol van az otthon. Brak szerint az otthon egyfelöl a mitikus vágyakozás helye a diaszpóra fantáziájában: az, ahová már nem lehet visszatérni, még ha meg is lehet látogatni azt a földrajzi helyet, ami után a kivándorolt szülőhelyeként, így otthonaként sóvárog. Azért nem lehet visszatérni, mert ez a hely maga is, a kivándorolt emberrel együtt, megváltozott. Ahogy Csipirka, Janiék távoli rokona mondta egyszer nekem, miután Torontóból, feladva a család menekültstátusz kérelmét, a férj kibírhatatlan honvágya miatt, hazatértek, hogy majd néhány hónap otthonlét után már Angliában próbáljanak újra szerencsét: „hát, tudod, úgy tudnám ezt mondani neked, hogy hiába húz az ember szíve haza is, mert húz, az biztos, mert mind hazavágyunk... De néhány hónap alatt újra beleundorodunk abba, amit itthon látunk. Ez már nem ugyanaz a hely, a mi falunk is megváltozott... Itt nincs jövő, nincs megélhetés. Az emberek le vannak pusztulva. Én is hazajövök, időröl időre Angliából, mert hiányzik a család, mert nekem itt vannak a gyerekeim meg az unokáim, hát hol tudok én meglenni nélkülük? De ha meg itthon vagyok, már egy hét után arra gondolok, hogy Istenem, minek jöttem én haza?” (Így aztán Csipirka is digitálisan tartja a rokonsági kapcsolatokat Angliából, két hazatérés között).

1 Hannerz, Ulf: Flows, boundaries and hybrids: keywords in transnational anthropology. WPTC-2K-02. Department of Social Anthropology, Stockholm University, 1989.

2 Brak, Avtar: Cartographies of Diaspora. Contesting Identities. Routledge, 1996. 
Másfelől az otthon a „lokalitás megélt élménye”, a tartós, intim kapcsolatokban, netwörkökben lakozó odatartozás (be-longing) és a valamivé válás (becoming) helye (Brak 1996), ${ }^{3}$ amit az általam ismert kanadai roma menekültek a digitális rokonság gyakorlatának kifejlesztésével és mindennapi fenntartásával igyekeznek belakni. E kétfajta otthonértelmezésből fakad az a feszültség, amit kutatóként igyekszem értelmezni a „hazájukból” az általuk tapasztalt intézményi rasszizmus miatt kivándorolt roma menekültek esetében. A feszültség, ami úgyis leírható, hogy miközben mindannyian hangsúlyozzák, hogy Torontó szabadságérzetet ad a sokszínüségével, azzal, hogy itt mindenféle, fehér, barna és fekete börü náció él együtt, hogy itt nem cigányként kezelik öket, hanem emberként, ahol van megfelelő színvonalú iskoláztatás, amivel ,jövőt tudnak adni a gyerekeik kezébe" - eközben a roma menekültek szinte mind vágynak ,haza”, vissza a szülőföldjükre, Magyarországra, mert ,a szív az hazahúz”. Ezt a hazavágyódást, a jogi korlátozás (menekültként nem hagyhatják el Kanadát) és a hatalmas fizikai távolság miatt a digitális rokonozás mindennapi gyakorlatával enyhítik. Az otthon így válik egy transznacionális virtuális térré, amelybe ugyanúgy beletartozik az éppen adott, sürün váltogatott fizikai lakóhelyük Torontóban, mint az otthonhagyott szülői vagy családi ház, annak lakóival, a közeli rokonokkal és velük együtt a nagycsaládi intimitás megélésével együtt.

3 Uo. 